
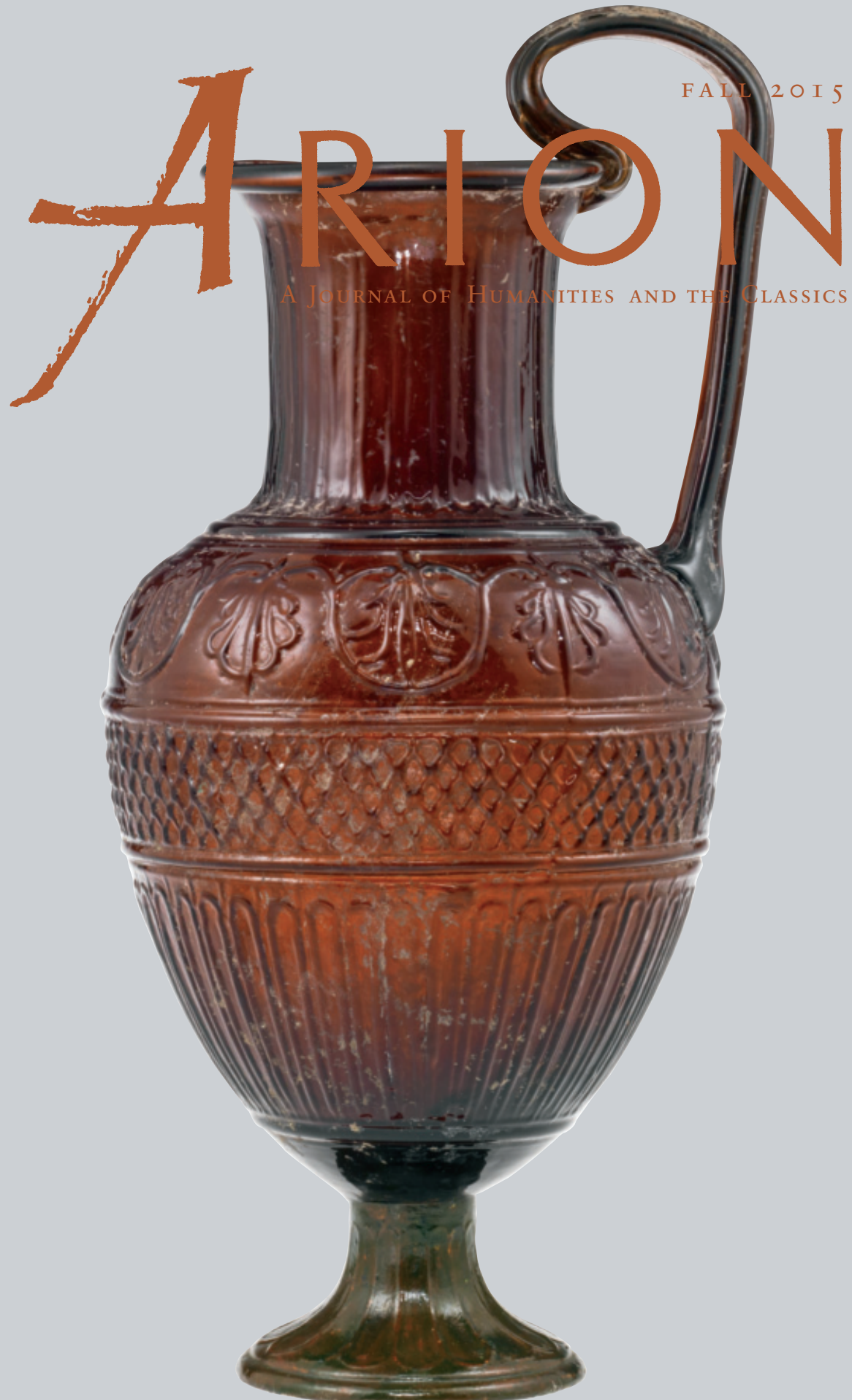

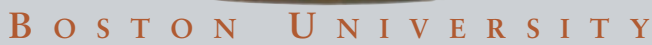




\section{The Unsettled Settler: \\ Herakles the Colonist \\ and the Labours of Marian Maguire}

GRETA HAWES

Could we imagine a new set of adventures for that old adventurer, Herakles? What would he have gotten up to, for example, in colonial New Zealand? In Herakles Writes Home, a striking lithograph from Marian Maguire's The Labours of Herakles, the black-figure hero scribbles away inside his wooden homestead. The distinctive, conical peak of Taranaki seen through a window locates the scene on the western cape of New Zealand's North Island. Above his head, Māori carvings-pressed into new service as bookends-guard a small library which takes in Homer, the Bible, and accounts of life in the South Pacific. A GreekMāori dictionary hints at the practicalities, and problems, of cross-cultural translation; the ongoing effort of understanding, and the constant battle to be understood. Frederick Maning's Old New Zea-

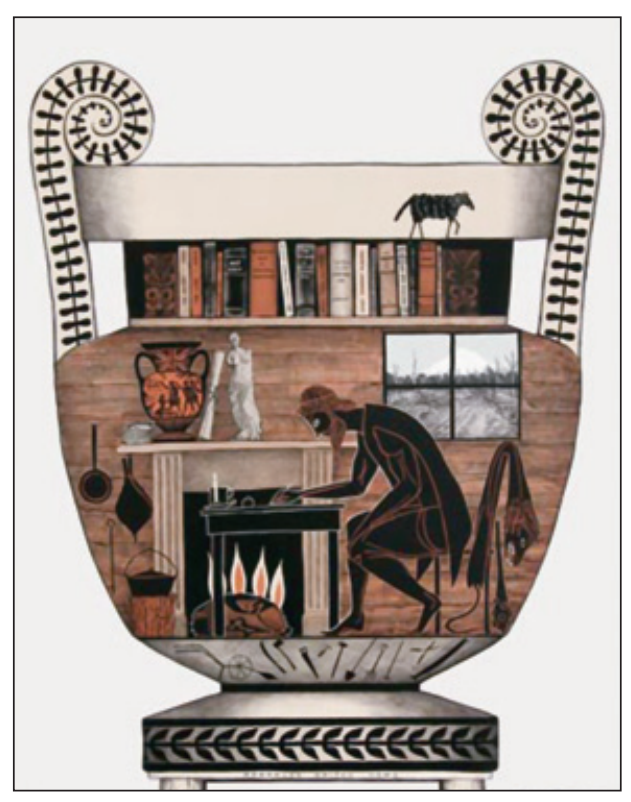

Fig I. Herakles Writes Home. 
land would offer mediated insights of another kind. Written by one of the most famous Pākehā Māori, ${ }^{\mathrm{I}}$ it is an account of Māori culture written for a European audience by a man at home in both worlds.

This arresting scene of disjunctive, recycled motifs and shifting cultural touchstones is typical of Marian Maguire's four major series of lithographs and etchings, which re-imagine New Zealand's colonial past through the lens of ancient Greek imagery. The first series, Southern Myths (200I-3), sets episodes from the Trojan War against a backdrop of New Zealand landscapes. The Odyssey of Captain Cook (2005), narrates the first encounters between the English explorer and Māori. The Labours of Herakles (2008), takes up the theme of colonization by making the ubiquitous hero a European settler. It is this series-extensively exhibited in New Zealand and now touring Europe-which I will discuss here. Maguire's fourth and most ambitious series, Titokowaru's Dilemma (20II), again jumps forward in time, to the New Zealand Wars (I 845-72) and examines the complex internal and external struggles of the skilled military leader and sometime pacifist, Riwha Tìtokowaru of Ngāti Ruanui. Each of these series displays the intricate resonances of Greek antiquity as a vehicle for thinking through our sense of the past. And "our sense of the past," in Maguire's work must be experienced severally: our sense of a Western tradition; our sense of a Pacific nation with its own particular history; our sense of the translation of cultures; our sense of a process of colonization whose ramifications are still readily apparent.

By presenting the past as it did not occur, Maguire's work forces us to look more closely, and to think about where we stand. Its apparent whimsy prompts much side-ways thinking. Hers is a visual vocabulary full of ambiguity and paradox. As we examine these images we contend with shifting perspectives, and unravel complex visual puns The magical realism of her new vision of the past is designed to provoke responses. My own derive from my personal interest in understanding 
the land of my birth, and my professional one in the uses of Greek myth. My responses to it, as set out here, speak to the paradox of a subjective experience within the shared resonances of communal vocabularies-cultural mythologies, writ broad. The addition of an ancient hero-Herakles-to the stories of New Zealand's history is no superficial gimmick. New Zealanders are accustomed to understanding their country's identity through the image of the meeting of two cultures: Polynesian and European. On New Zealand's coat of arms, a young, pale-skinned Pākehā woman stands on the left, a Māori warrior on the right. Maguire's work transforms this familiar dynamic into a kind of triangulated arrangement. Māori, European, and ancient Greek encounter each other in various ways. The Greek hero is never simply an avatar of the European colonist; his role is more subtle than that. There can be, then, no easy binary of experiences. Maguire's work is unsettling - subversive, even-in this way as it creates a fluid, alternate reality which models the past in quite profound ways, but does not replicate it.

The Labours of Herakles refuse to champion a single, victorious point of view. Instead, they lithely convey several stories concurrently. In doing this, they embody visually the turn away from the "grand narrative" style of history and towards a more fragmented, partial, multi-faceted one. This multi-perspective vision of the past has also distinguished the best work on the Pacific in the last few decades. Herakles himself has this way of thinking within arm's reach. On the bookshelf in his homestead sits Anne Salmond's The Trial of the Cannibal Dog (2004). This detailed account of the voyages of James Cook in the South Pacific turns on the theme of inter-cultural contact, communication and transformation. Captain Cook's small wooden vessels introduced to the Pacific a radically new worldview. This was no event of unilateral cultural imposition, however, nor indeed a strictly bilateral encounter. What might elsewhere be described superficially as a "clash of cultures" becomes, in Salmond's hands, a complex, manifold picture of human diversity: 
curiosity and fear, generosity and mistrust, friendship and profiteering, ethnographic study and misconstrued intentions, perceived offences and retribution. Cook brought into the South Pacific new technology, new customs and conventions, new forms of military and social hegemony, new livestock, and new diseases; but Polynesia, likewise, was full of novelty and innovation. This set of encounters, then, required responses from both sides and no one-least of all Cook and his floating Europeans-escaped unchanged.

In Salmond's account, Cook's long voyages of exploration transformed his personal worldview; the pragmatic sea captain from Whitby, citizen of an Enlightenment England now foreign to us, navigated and charted not merely the seas of the Pacific, but its cultural currents. As he sought to make sense of, and to exploit, those he met, his horizons changed. He entered into ceremonial friendships with elites across Polynesia becoming, knowingly or not, embroiled in ongoing political, military, and religious disputes. His story ends with the long third voyage, during which even his own men came to refer to him by his Polynesian name, Toote. He was greeted as an ancestral spirit in Hawai'i, but his violence was ultimately countered with hostility. He was killed, stabbed with an iron dagger brought to the island on his own ships, and his body ceremonially dismembered. As Herakles writes home, The Trial of the Cannibal Dog, securely nestled on a bookcase, hovers ominously above his head. What lessons might this Greek hero, once beset by a ferocious, man-eating dog in his own life, draw from the story of Cook in the Pacific? Here was another mythical voyager, also sometimes semi-divine, who also died a violent death and came to be remembered variously as a beacon of civilization, and as an agent of barbaric destruction.

Herakles' energies, in any case, are clearly taken up with transformations of a different sort. Through the window of the homestead, we see the fruits of his labors-a farm takes shape in land half-cleared of its forest. Herakles' heroic efforts on the slopes of Taranaki will create the lush pastures for what is now a booming dairy industry. For the moment, though, we 
see only the backbreaking work of clearing the land. This is the practical side of colonization, making inroads into the interior and rendering it useful to support a new way of life. But Herakles is not landscaping an empty hillside. What might seem a modest, necessary bush track to one bystander, is intrusive to another. In the late I870s and '8os, the Māori community at Parihaka, not far from Herakles' little homestead, waged a long campaign of non-violent resistance in the face of ongoing land confiscations. ${ }^{2}$ They built fences across roads like this one and ploughed up encroaching farmland, protesting the realities of ownership in ways both practical and symbolic. Progress is an ambivalent concept. Do we look out through Herakles' window and nod appreciatively at the emerging order of agricultural industry, or do we mourn this scene as just another episode in the "struggle without end"? What kind of history do we see forming here?

Inside the homestead, the accoutrements of Western civilization are certainly apparent. This Herakles is a collector of souvenirs. On the mantelpiece sits an amphora depicting Captain Cook in black-figure; there is a postcard from ancient Greece and a tourist statue of the Venus de Milo (from the gift shop in the Louvre? we ask ourselves). Surrounded by his smug cultural baggage, Herakles is caught up in a mood of quiet, industrious concentration. "Writing home" is an activity redolent of nostalgia. It conjures up the image of bonds stretching across the ocean, back to what poet Denis Glover would later describe derisively as "quaint old England's / quaint old towns." 4 And yet that innocuous phrase, "writing home," hides any number of realities—divided loyalties, difficult pasts and strained relationships. For any number of reasons one might relocate-or be banished-to the other side of the world. To whom does Herakles write from this outpost in the South Pacific? To his murdered wife and children? His absent father? His ever-hostile stepmother? Where would be "home" for him? Maguire's Herakles fits into New Zealand's colonial history as he fits in anywhere: he is a recognizable individual: 
eye-catching, solitary, larger than life, and always somewhat out of place. And in this cycle he is also somewhat out of time. This is the joke of the bookcase. Herakles could reach up and open Aristotle's Discourse on Place and Time; we have no testimonia for such a work, but that is not to say that a denizen of antiquity could not have known it. Our time-travelling colonist is also well read in the new classics of ethnography and science: he has Cook's journals and Darwin's On the Origin of Species; but he can also scan Salmond's postcolonial commentary. He has books which give practical advice on colonial life, but also Old New Zealand: A Tale of the Good Old Times, written in 1863 by Frederick Edward Maning, who had lived as a Pakeh Māori in the I83os and I840s. His account seeks to provide a record not merely of true pioneer adventure for a milder later generation, but of a way of life amongst both Pākeh and Māori then largely gone. The nostalgic Maning is a neat parallel for our Herakles. This Greek hero is not merely out of place on his deforested hillside. He is also a relic of a different age, and this, too, is in keeping with convention: how much comfort might he derive if he were to reach up and grasp the Iliad or the Odyssey, in which he was already, to the more discerning Greeks of the archaic period, an outmoded hero?

Maguire's skillful compositions attract the eye with their elegant design and clever visual puns. But the weaving of Greek myth and art into the narrative of New Zealand history is no mere pastiche. It offers a deeply unsettling perspective on this familiar material. Beyond the witty in jokes lurk a series of troubling questions. Herakles is a convenient cipher for figuring the messy dynamics of colonization in the South Pacific. He introduces a necessary element of intellectual distance being, at once, an archetype of Western culture, and nobody's true ancestor. His sojourn in New Zealand, then, is at once both obviously fictional, and-or, rather, therefore-deeply emblematic of something else. Maguire's disjunctive rendering creates deft commentary out of an 
unsettling blend of innovation and familiarity. She creates a recognizable world which is not quite as it was, but nevertheless clearly becoming something like what it will be. Her decontextualized, anachronistic, constantly shifting fragments make the commonplace seem foreign. This Herakles is a tourist, he doesn't belong, and will soon move on. After all, he always did. Even in antiquity, Herakles seldom lingered in one place long enough to put down roots. Vagrancy is an integral part of Herakles' character. It is also an index of his popularity as a cultural cipher, one that can be molded at will. Maguire has said of Herakles that "[y]ou can get [him] to do anything you want." 5 Exploitation of his malleability is not an exclusively modern conceit.

Herakles has never been a single figure; in antiquity he was an amalgam of different useful properties. His mythology was loosely unified by the canonical Labors, but admitted flexibility, diversity and paradox. He can be said to embodybroadly-a corporate vision of Greek identity (he is the "the one true Panhellenic hero" 6 ) yet he remained distinctly rootless. He was a possession, in various ways, of all Greece but never restricted solely to any one location, or any one particular role. It was this adaptable homelessness which made him the perfect colonizer. The malleable plasticity of Herakles came into play as the Greeks sought to make sense of a widening world. Herodotus, for example, talks of the Herakles revered amongst the Egyptians and attempts to reconcile this figure with Greek traditions, concluding that the Greek hero must be merely a replication of the older Egyptian one (2.42-45). Here, then, Herakles is no longer a familiar figure of Hellenic exceptionalism. Finding Herakles in Egypt forces Herodotus to adopt a new perspective, to see his own culture from the outside. 7 This model of religious syncretism emerges, too, at prominent points of contact, like western Sicily, where his cult became fused with that of the Phoenician Melqart. ${ }^{8}$ In the expanding world of the ancient Mediterranean, then, Herakles could serve as an agent of translation, providing a point of cultural overlap between the Greeks and their neighbors. 
But this sense of colonization as a fluid and reciprocal process tends to be lost in the basic plots of myth. Herakles' wide-ranging journeys provided a unifying framework for the geographically diffuse Greek world. Stephanos of Byzantium lists twenty-three cities named "Herakleia" ("city of Herakles") scattered across the Greek world (Ethnika 303-4). As a prominent founder, Herakles was a centralizing figure through whom colonies could connect themselves to a conceptual Greek homeland; they had followed in Herakles' footsteps, and thus inhabited land once associated with him.9 So, for example, Herakles' journey westward in search of Geryon's cattle provided a convenient peg for the charter myths of the Greek cities of Sicily and southern Italy. Three very similar stories, from Croton, Locros and Abderos have Herakles as the accidental murderer of a friend on these sites. He then either prophesies or orders the future construction of a Greek city by the tomb of its now-eponymous hero. In this way, his activities legitimated and made inevitable later Greek expansion into this area; the Greeks had not simply claimed this land, they had re-claimed it.

Herakles' journeys domesticated the wider world; his actions opened up the Mediterranean, making it suitable for habitation. Most famously, he re-landscaped the Straits of Gibraltar, creating a narrow channel which blocked the ingress of sea monsters (Diod. Sic. 4.I 8.5). Diodoros describes Herakles' killing of the giant Antaios as part of a broader ideological program, with Herakles working to create the prosperous world of the historical present (4.17.4, my translation):

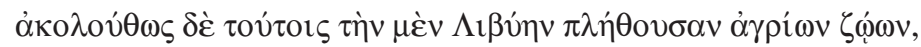

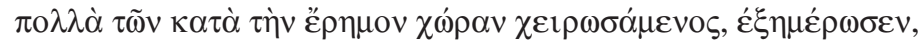

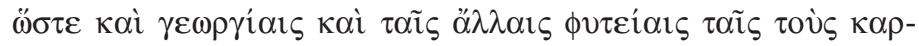

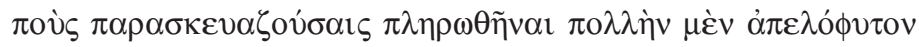

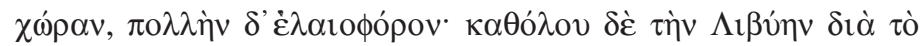

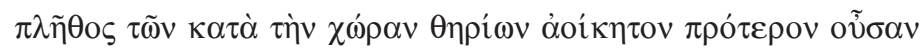

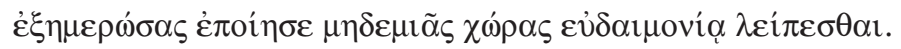




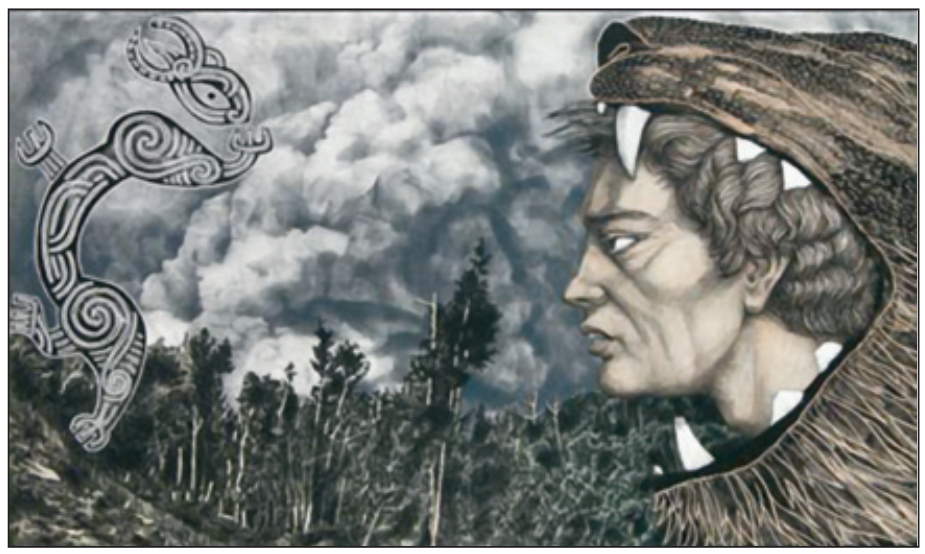

Fig 2. Herakles Clears the Land.

After [defeating Antaios], he subdued Libya, which was at that time full of wild beasts, and much of the wasteland beyond it. He tamed this land so that it could be covered with pastures, fields for crops, and other fruit-bearing plants. Much was given over to vineyards, much to olives. On the whole, he tamed Libya, a land previously uninhabited on account of the great number of wild beasts which ranged across it, and he made it second to none in its prosperity.

Here Herakles enters a land devoid of people and leaves it a safe and useful space. Seen from this perspective, Herakles is a straightforward agent of civilization and progress. We can certainly find anxiety elsewhere in antiquity regarding the value of Herakles as a model for ethical behavior. Likewise, we might recognize some irony in the fact that Herakles' constant wandering is an index of his inability to settle properly into the kinds of political life which he was said to have established everywhere. But such ambiguity is seldom explicitly highlighted in his ancient role as a colonizer. This particular facet of his heroism afforded only unproblematic benefits to those who come after him. Civilization and the imposition of Greek values and Greek economic priorities are, in this way of thinking, one and the 
same; and the land must be tamed, by force if necessary, for them to flourish.

Maguire's Herakles is not the founder and initiator of colonies, like his ancient counterpart, nor an explorer, like his precursor Captain Cook. Rather, he is a settler, engaged in the tedious, backbreaking work of occupying a new land. This Herakles cannot simply conjure up a transformation as the ancient one did in Libya. Herakles Clears the Land (fig. 2) offers a vision of what such transformation entails. A wooded hillside is half-cleared of trees; a fence marks the new boundaries of this emergent paddock. Above, smoke billows into the sky as Herakles burns off the bush to clear land for farming. "Clearing the land" turns out to be another ambivalent phrase. Herakles is not only burning off forest to carve out his farm; he is also asserting his ownership over this parcel of earth, manipulating it to his needs. He is part of a massive environmental revolution which transformed large tracts of New Zealand into open grassland through the $19^{\text {th }}$ and early $20^{\text {th }}$ centuries. Diodoros described Herakles' efforts in straightforward terms as the removal of monsters, the institution of agriculture and the arrival of its attendant prosperity; here we see a different scene redolent of the dark heroism of the colonial program, and its intractable consequences. The ancient Antaios, connected as he was to Gaia, might be understood in Diodoros as a figuration of the wilderness which inhibits human habitation. In clearing his patch of New Zealand, Herakles sees off a different kind of monster: a taniwha made homeless by the fire flees to the left of the image. Taniwha are supernatural creatures in $\mathrm{M}^{-}$ aori thought. They play many roles: some are destructive, others act as personal or tribal guardians. They are usually associated with specific places, or bodies of water; disrupting that environment risks disturbing its resident taniwha. ${ }^{\text {Io }}$ Herakles' model of economic value, based on dairy cattle and demarcated hectares, leaves little room for cohabitation. 
But the taniwha is no straightforward symbol of nature; and perhaps neither is Antaios. One man's monster is another's protective spirit. What goes unsaid in Diodoros' passage becomes clear in Maguire's rendering of the fight. Taniwha are not integral to the New Zealand landscape as such, but to a distinctive Māori perspective on it. In toiling towards his vision of civilization and prosperity, Herakles not only converts the land to new use, but imposes his own, Victorian assumptions onto it. British legal structure frequently proved at odds with Māori conventions. New Zealand's colonial history is unusual in that sovereignty over this landmass was ceded to Britain by mutual treaty. The Treaty of Waitangi was signed in I840. It circulated in two languages: Te Reo Māori, and English. These two versions were different; the two languages could not convey the same meaning given that these languages encoded vastly different cultural conceptions. In the two versions of the Treaty, incompatible understandings of concepts like "sovereignty" and "ownership" sit side by side, and legal debate over exactly what was agreed continues to this day in the Waitangi Tribunal. II British law could not account for the subtleties of Māori land tenure. In Māori thought, humans are the descendants of Tanemahuta, the god of the forest, and Hineahuone, a woman created by him out of clay. The relationship between humans and their environment is thus in part a genealogical one. In practice, land rights were claimed through a combination of ancestry, kinship, political control, communal negotiation, and social recognition. Customary tenure could be connected to the visibility of fire, but not in the manner of Herakles' burn off. Continued occupation of a territory was associated with te abi ka $\bar{a}$, the cooking fire burning constantly on the land.

In the decades that followed the signing of the Treaty, dispute over the nature of this agreement and radically different models of ownership came up against each other, and against swiftly changing social, political and economic values. In these battles_-both legal and military_for land, we often 
miss the less visible historical shifts in the right to assign conceptual significance to landscapes. With the transferal of land and its transformation, one set of stories ceased to be told, and another grew up. In ridding his new land of its resident taniwha, Herakles is clearing this paddock of the genealogical and mythological traditions to which it once belonged. In their place, he creates a new mythology, one which is imported, but transformed by native conditions. Maguire describes her first series, Southern Myths, as an attempt to explore the question of whether "myths clash when they occupy the same territory, and whether introducing a new story equates to mythical imperialism." 22 The pictorial and narrative vocabulary that Maguire has developed invokes the interweaving of different cultural strands on New Zealand soil; the particular image of Herakles clearing the land, however, offers a less optimistic view of the possibility of co-existence. Nonetheless, the cultural triangulation allowed for by the depiction of a Greek hero as a European settler in the Pacific does not settle comfortably into diametrical dichotomies, and this is part of the power of Maguire's work. Burning off standing bush is hot, dirty work, and Herakles' face is lined with ash. There is a new weariness to his features; he seems gaunt, haunted even. His lion's skin still snarls menacingly around him, but its teeth are chipped and worn. This is not the black-figure hero of the cabin, with its single, expressionless eye in profile. This Herakles in fact has the features of "Matai," a chief sketched by Louis Auguste de Sainson on his visit to New Zealand in the I $820 \mathrm{~s}$, but lacks his tattoos. Our Herakles, then, has begun to be transformed by his environment, even as he works his own transformations on it.

As Herakles labors over his desolate patch of future farmland, he dreams of Arcadia (fig. 3). Arcadia will always be a pastiche, as it is here. Herakles knew an Arcadia: that particular region of the Peloponnese was once home to the Erymanthian boar. But the Arcadia depicted here is an indistinct wilderness, the idealized scenery of Enlightenment 
painters. The place is thus not a place, but a cultural touchstone, an idea and not a destination. As Herakles digs away on his land, desolate as far as the eye can see, he reaches for an aesthetic ideal. But where does this ideal reside? The Arcadia of Greece is part of his homeland-so perhaps he mourns its loss. But new Arcadias might also be built on foreign shores. Indeed, they might be found anywhere on Earth: reports and images produced by Cook's voyages depicted the Pacific as a kind of Arcadian idyll.' 3 Does Herakles' labor, then, create or destroy his dream? In either case, Arcadia is unattainable: Cook's artists might have seen the South Pacific through a classical lens, but this was not the reality; one cannot inhabit an idyll. Herakles' dream is a failure of the imagination: why should one place be made to look like another? And how practical a model would an otherworldly utopia provide, anyway?

This impossible dream of a verdant spot free from work or worry has an ominous subtext. In Arcadia, the rabbit held by the maenad might be understood as a symbol of the region's easy fertility. But in New Zealand, this gift proved destructive. Within a few decades of their introduction, rabbits had

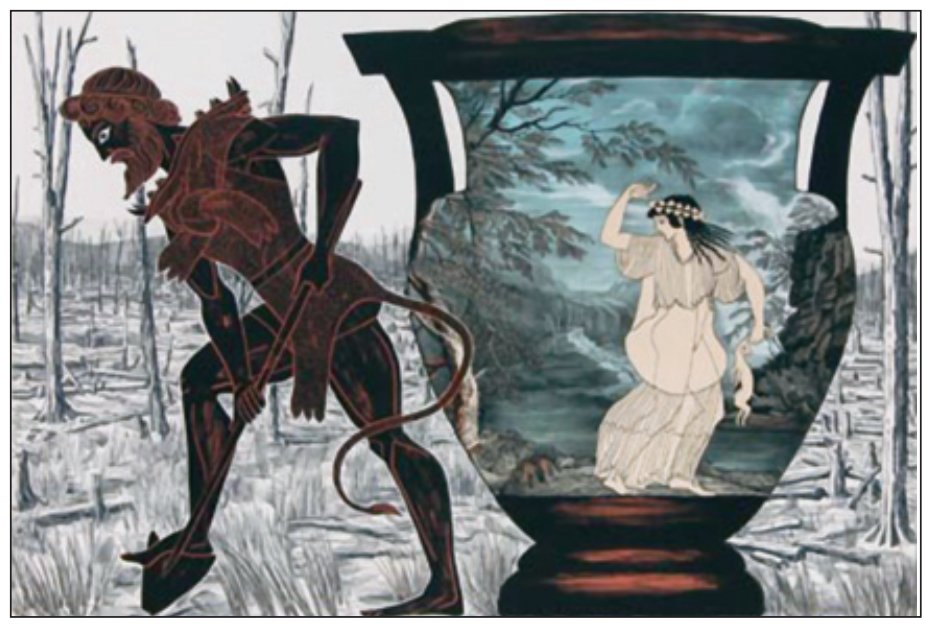

Fig 3. Herakles Dreams of Arcadia. 


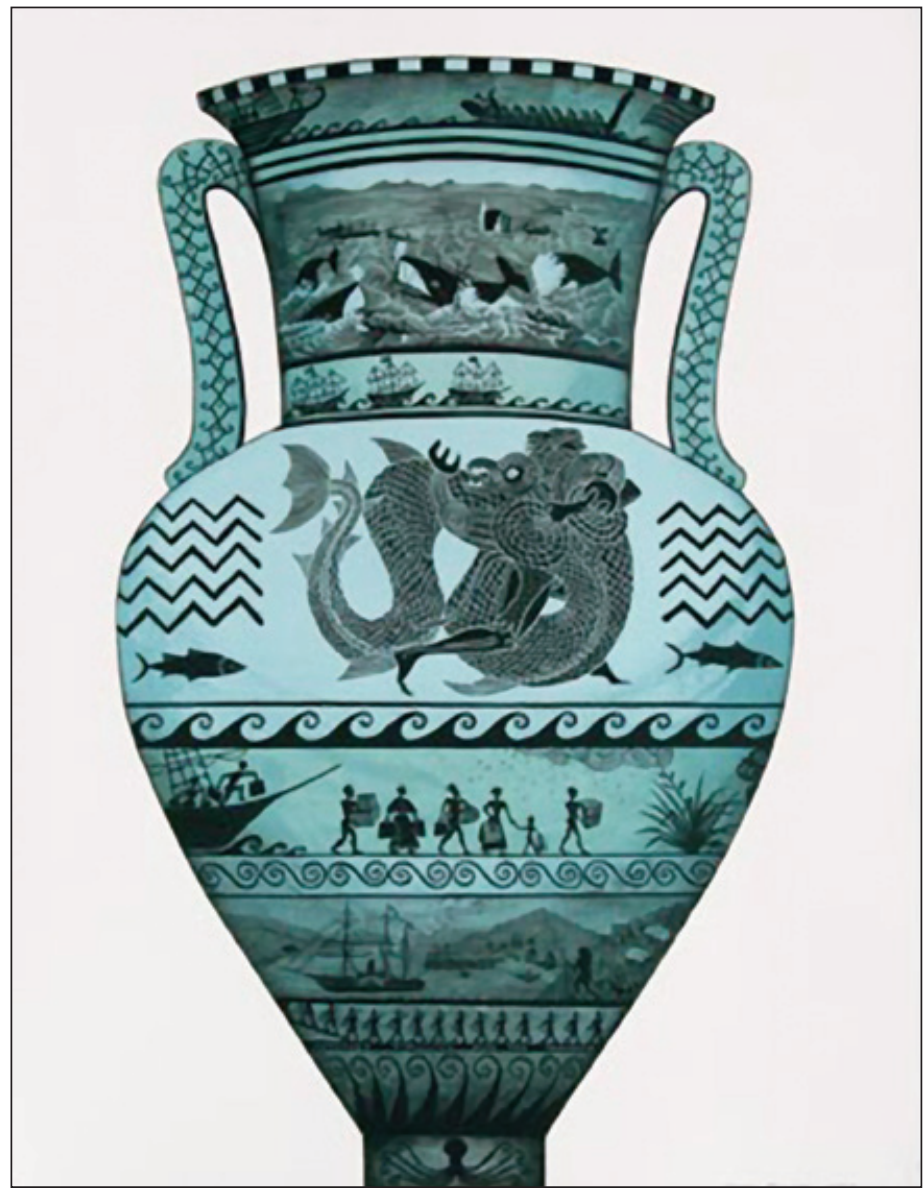

Fig 4. Herakles Struggles with the Taniwha.

ruined great tracts of farmland; they now require constant culling. Alongside the deforestation which so marks New Zealand's current landscape, rabbits and other introduced mammals encapsulate the changes wrought by scarcely a millennium of human inhabitation (Polynesian and European). Just like his ancient counterpart, this Herakles re-landscapes his world. Where in antiquity colonization could be plotted as the simple act of translating an unknown location into a Greek one, ${ }^{\mathrm{I}} 4$ our postcolonial world shows this transformation to be partial and fraught. Herakles will not create, or 
indeed recreate, Arcadia; these islands could not become a new Arcadia just as they did not become a new Britain, as they were billed to be, or even a new Zealand, as Dutch cartographers would have had it. The nation that Herakles helps to build has its own history, and its own contingencies.

So, where does this leave us? The relationship between antiquity and modernity should be unsettling. Maguire's Herakles should send us back to the Greek stories of colonization, and spur us to think about the ways in which ancient myths can plaster over any number of difficult realities. The fact that Diodoros describes Herakles' civilizing labors without mentioning the toll they might have taken on him personally becomes a telling silence; the idea that he cleared virgin territory only of monsters and wild beasts becomes a happy fiction. What does the ancient Herakles, by contrast, bring to Maguire's work? In short: his own brand of unsettling complexity. His sojourn in the South Pacific introduces chaotic perspectives on time and place. It is narrated via a visual vocabulary which forces the viewer to reconcile the disjunctive nature of colonization, and to confront postcolonial questions about belonging, cultural authority, and ownership. As a foreign, imported hero, he introduces a modicum of intellectual distance: this is not a direct narrative of colonization, but one triangulated through the world of myth, and in this new mythic world, the viewer has a different investment. But this new myth of Herakles, for all its deliberate symbolism, does not give us another colonizing automaton. The new environment effects its own transformations, chipping away at the hero's characteristic resolve, and his aloofness. Like Captain Cook in Salmond's account, Herakles does not escape unchanged. The Herakles of antiquity is always victorious, even to the point of winning a kind of immortality. In Maguire's series, by contrast, one becomes increasingly unsure of what in fact constitutes triumph and defeat. The final lithograph in the series (fig. 4) shows Herakles locked in perpetual combat with the taniwha. But unlike the fight with Antaios, this is no easy victory. The tri- 
umphalism of imperial heroism rings hollow. We leave Herakles, then, intertwined ambiguously with this new monster, subsumed by him, one grasping the other in a strange embrace, neither winning nor losing.

\section{NOTES}

For those interested in looking at Marian Maguire's work in more depth, her website (http://www.marianmaguire.com/) is the best place to start. Her beautifully-produced exhibition catalogues reproduce the series alongside detailed commentary and responses from prominent New Zealand writers. Beyond this, there is also Elizabeth Rankin's "Negotiating narrative interstices: the lithographs and etchings of Marian Maguire" in Luke Morgan, ed., IMPACT 7: Intersections and Counterpoints (Melbourne 2012). I would like to thank Marian for her help with various queries, and for granting permission to reproduce the four images which illustrate this article. I would also like to thank Hannah August, who read an earlier draft of this article and provided an insightful set of new perspectives at a crucial point.

I. Pākehā is the typical term used to describe New Zealanders of nonPolynesian descent. Pākehā Māori are non-Polynesians who, for various reasons, lived among the Māori for extended periods of time in the early phases of European settlement. A good account of them can be found in Trevor Bentley, Pakeha Maori: The Extraordinary Story of the Europeans Who Lived as Maori in Early New Zealand (Auckland and London 1999).

2. One of the best accounts of the events at Parihaka remains the book which first brought them to the attention of the modern nation: Dick Scott, Ask That Mountain: The Story of Parihaka (Auckland I975).

3. Ka whawhai tonu matou / Struggle Without End is the title of Ranginui Walker's I990 history of New Zealand, written from a Māori perspective.

4. The lines are from Denis Glover's “Home thoughts" (I936):

I do not dream of Sussex downs

or quaint old England's

quaint old towns

I think of what may yet be seen

in Johnsonville or Geraldine.

5. Quotation is from an interview with Rosa Shiels, "Herculean NZ," The Press i r.6.08.

6. G. Karl Galinsky, The Herakles Theme: Adaptations of the Hero in Literature from Homer to the Twentieth Century (Oxford I972), 3.

7. There is a good discussion in Ian S. Moyer, Egypt and the Limits of Hellenism (Cambridge 20II), 78-82.

8. For discussion of Herakles and the Phoenician Melqart, see Irad 
Malkin, A Small Greek World: Networks in the Ancient Mediterranean (Oxford and New York 20II), chap. 4.

9. For a survey of Herakles' activities as a founder, see Emma Stafford, Herakles (London 2012), I 56-60.

Io. In a well-known case in 2002, the Waikato tribe Ngāti Naho successfully argued that the proposed route of a new highway should be changed so as not to disrupt the lair of the taniwha Karutahi.

I I. For the two versions of the Treaty, and explanation of their differences, see http://www.nzhistory.net.nz/politics/treaty/read-the-treaty/english-text

I2. Quoted in an interview with Jessica Hughes, Practitioners' Voices in Classical Reception, vol. 3 (2012).

I3. See Bernard Smith, European Vision and the South Pacific, 2nd ed. (Sydney I984).

I4. For the language of Greek colonization as an act of domestication, see Carol Dougherty, The Poetics of Colonization: From City to Text in Archaic Greece (Oxford I993), esp. 45-5I. 
INSIDE THIS IsSUE:

JANE Alison on ancient narrative today

Greta Hawes looks at the Labours of Marian Maguire

Four poems by Ricardo PaU-Llosa

James Como investigates why Shakespeare went to school

Douglass PARKer: Zukofsky versions of Horace

Margaret Malamud on an abolitionist use of the classics Two Poems by Katie Hartsock

The Coming Classics Revolution: Part Two, Colin Wells Athena, Daphne by Diskin Clay

Marianne McDonald on the mythical in Monteverdi Thomas McCreight translates more of Apuleius The Five Paragraph Essay, Will Desmond

Three Poems, P. Whalen

Paul BAROLSKY on the interpretation of art Stephen Scully on lost epics 